\title{
MORPHOGENESIS OF GALLS INDUCED BY Baccharopelma dracunculifoliae (HEMIPTERA: PSYLLIDAE) ON Baccharis dracunculifolia (ASTERACEAE) LEAVES
}

\author{
ARDUIN, M. ${ }^{1}$, FERNANDES, G. W. ${ }^{2}$ and KRAUS, J. E. ${ }^{3}$ \\ ${ }^{1}$ Department of Botany, Federal University of São Carlos, C.P. 676, CEP 13565-905, São Carlos, SP, Brazil \\ ${ }^{2}$ Department of General Biology, Institute of Biological Sciences, Federal University of Minas Gerais, \\ C.P. 486, CEP 30161-970, Belo Horizonte, MG, Brazil \\ ${ }^{3}$ Institute of Biosciences, University of São Paulo, USP, C.P. 11461, CEP 05508-900, São Paulo, SP, Brazil \\ Correspondence to: Marcos Arduin, Department of Botany, Federal University of São Carlos, \\ C.P. 676, CEP 13565-905, São Carlos, SP, Brazil, e-mail: darduin@ power.ufscar.br
}

Received February 2, 2004 - Accepted March 31, 2004 - Distributed November 30, 2005

(With 33 figures)

\begin{abstract}
The commonest insect gall on Baccharis dracunculifolia (Asteraceae) leaves is induced by Baccharopelma dracunculifoliae (Hemiptera, Psyllidae). The gall-inducing insect attacks young leaves in both the unfolded and the fully expanded stages. Four developmental phases were observed in this type of gall: 1) A folding phase, during which the leaf lamina folded upward alongside the midrib and the edges of the upper portion of the leaf approached each other, forming a longitudinal slit. A single chamber was formed on the adaxial surface of the leaf; 2) A swelling phase, in which the folded leaf tissues thickened and the edges of the leaf drew closer together, narrowing the slit. In this phase the gall matured, turning succulent, fusiform and pale green. The single nymphal chamber was lined with white wax and was able to house from one to several nymphs; 3) A dehiscence phase, characterized by the opening of the slit to release inducers; and 4) A senescence phase, when the gall turned dark and dry. The dermal system of the mature gall was composed of a single-layered epidermis. The mesophyll was swollen, and the swelling was due mainly to hyperplasia of the parenchyma. The vascular tissues along the midrib vein were conspicuous and the perivascular fibers resembled parenchymal cells. The hypertrophied secretory cavities contained low lipophylic content. This gall does not form nutritive tissue, but salivary sheaths left by the inducers were observed near the parenchyma, vascular bundles and secretory cavities. This study complements our current knowledge of gall biology and sheds further light on the plasticity of plant tissues stimulated by biotic factors.
\end{abstract}

Keywords: leaf galls, Baccharis dracunculifolia, Baccharopelma dracunculifoliae, morphogenesis.

\section{RESUMO}

\section{Morfogênese das Galhas induzidas por Baccharopelma dracunculifoliae (Hemiptera: PSYLLIDAE) em folhas de Baccharis dracunculifolia (Asteraceae)}

Morfogênese das galhas induzidas por Baccharopelma dracunculifoliae (Hemiptera, Psyllidae) em folhas de Baccharis dracunculifolia (Asteraceae). A galha entomógena mais comum em folhas de Baccharis dracunculifolia (Asteraceae) é induzida por Baccharopelma dracunculifoliae (Hemiptera, Psyllidae). O inseto galhador ataca tanto folhas jovens não distendidas quanto as completamente distendidas. Quatro fases de desenvolvimento foram observadas nesse tipo de galha: 1) Fase de dobramento, na qual o limbo dobra-se ao longo da nervura central e devido à aproximação das margens, uma fenda é formada na porção superior da folha. Uma câmara única está presente na face adaxial da lâmina foliar; 2) Fase de intumescimento, em que a folha dobrada torna-se espessada e suas margens aproximam-se, fazendo com que a fenda se estreite. Nesta fase, a galha está madura, suculenta e fusiforme, apresentando coloração verde claro. A câmara ninfal abriga de 1 a vários indutores e é recoberta por cera branca; 3) Fase de deiscência, caracterizada pela abertura da fenda, liberando os indutores; e 4) Fase de senescência, quando 
torna-se escura e seca. O sistema de revestimento da galha madura é formado por epiderme uniestratificada. $\mathrm{O}$ mesofilo apresentou-se intumescido, devido principalmente à hiperplasia do tecido parenquimático. $\mathrm{Na}$ nervura central, os tecidos vasculares mostraram-se conspícuos e as fibras perivasculares com aspecto semelhante ao de células parenquimáticas. Nas cavidades secretoras hipertrofiadas, o conteúdo lipofílico era escasso. Nessa galha não se formou tecido nutritivo, mas foram vistas bainhas salivares deixadas pelos indutores junto ao parênquima, aos feixes vasculares e às cavidades secretoras. Os estudos feitos complementam as informações sobre a biologia da galha e contribuem para a compreensão da plasticidade dos tecidos vegetais estimulados por fatores bióticos.

Palavras-chave: galhas foliares, Baccharopelma dracunculifoliae, Baccharis dracunculifolia, morfogênese.

\section{INTRODUCTION}

The mouth parts of insects of the order Hemiptera form a proboscis that comprises mandibles and maxillae modified as needle- or thread-like stylets lying in a grooved labium. Two pairs of stylets interlock to form two canals: one delivering saliva and the other taking up plant or animal fluid (Gullan \& Martin, 2003). These insects extract nutrients from the phloem, xylem or non-conducting cell tissues of plants (Meyer, 1987). Therefore, hemipterous insects, including the free-feeding ones, damage plants by directly affecting tissues and by acting as vectors for many diseases (Hodkinson, 1974, 1984).

The gall-inducing species of Hemiptera are distributed into four superfamilies: Aphidoidea, Psylloidea, Coccoidea and Aleyrodoidea (Raman, 2003). Within the family Psyllidae there are nearly 350 widely distributed gall-inducing species occurring mainly on the leaves of dicotyledonous plants (Mani, 1964; Hodkinson, 1984). Psyllid galls usually contain only one nymph per chamber, but some galls have been found to house more than one nymph. Psyllid galls may have either simple or complex structures, and can be found either isolated or aggregated (Hodkinson, 1984; DregerJauffret \& Shorthouse, 1992; Raman, 2003).

The galls most frequently found on Baccharis dracunculifolia DC. (Asteraceae) are induced by Baccharopelma dracunculifoliae (Hemiptera: Psyllidae), formerly Neopelma baccharidis (Araújo et al., 1995; Fernandes et al., 1996; Burckhardt et al., 2003). Most studies on the galls induced by this psyllid have addressed ecological aspects of their interaction with the host plant. For instance, the distribution and external aspect of the galls, development, and biology of the inducer were addressed by Lara \& Fernandes (1994) and Araújo et al. (1995), while studies on the interaction of the psyllid with parasitoids were conducted by Sperber \& Collevatti (1996), Collevatti \& Sperber (1997), Espírito-Santo \& Fernandes (2002), and Ribeiro-Mendes et al. (2002). The influence of climatic conditions, leaf tannin concentration and the sex of host plants on Baccharopelma dracunculifoliae were investigated by Espírito-Santo \& Fernandes (1998, 2002), and Faria \& Fernandes (2001). Although various studies have been carried out on the natural history of Baccharopelma dracunculifoliae, none have addressed the ontogeny and histology of the galls formed on Baccharis dracunculifolia. Therefore, we are the first to describe the developmental phases of the gall and its morphological and anatomical aspects, hoping to shed further light on this system.

\section{MATERIAL AND METHODS}

Samples of young leaves and galls induced by Baccharopelma dracunculifoliae on Baccharis dracunculifolia were collected in Serra do Cipó, MG (southeastern Brazil), from an abandoned part of the MG-010 highway between kilometers 110-112. Specimens of Baccharis dracunculifolia containing galls were deposited in the Herbarium of the University of São Paulo Institute of Biosciences's Department of Botany (SPF) in São Paulo, SP, accession numbers SPF 77.102, SPF 77.103, SPF 78.039, and SPF 78.040.

Gall samples in various stages of development were fixed in buffered neutral formaldehyde (Lillie, 1948 in Clark, 1981), and in CRAF III (Sass, 1951, modified by the replacement of acetic acid with 
propionic acid). The material was processed for embedding in historesin (Sims, 1974) and sectioned (4 to $7 \mu \mathrm{m}$ ) with a rotary microtome. Histological sections were stained with a saturated solution of Sudan black B (C. I. 26150) in ethanol (Gahan, 1984 , modified by the use of $96^{\circ}$ GL ethanol) in order to detect lipids. After coloration, the sections were stained with $3 \%$ astra blue and $0.02 \%$ basic fuchsin (C. I. 42500), as described by Kraus et al. (1998). Lugol reagent was used to detect starch (Johansen, 1940).

\section{RESULTS}

\section{Morphology}

Baccharopelma dracunculifoliae induces gall only on young leaves, either completely expanded (generally $15 \mathrm{~mm}$ in length and located on the subapical portion of the shoot) (Figs. 1A and $1 \mathrm{~A}^{\prime}$ ), or just unfolded (located on the apical portion of the shoot, less than $15 \mathrm{~mm}$ in length) (Figs. 2A and 2A') of Baccharis dracunculifolia. One to several nymphs was observed in these galls. Four developmental phases of the galls were recognized: folding, swelling, dehiscence, and senescence phases.

Folding of the leaf occurred along the midrib, causing the leaf edges to come together and leaving a slit along the upper portion of the leaf; a single chamber was thus formed on the adaxial surface of the leaf, where the gall-inducing nymphs were located. When the induction occurred on an already expanded young leaf (Figs. 1A and 1A'), the folding of the leaf blade was not uniform. In this case, some parts of the leaf folded first (Figs. 1B ${ }_{1}$, $1 \mathrm{~B}_{1}$ ' and 3), resulting in a twisted shape (Figs. $1 \mathrm{~B}_{2}$, $1 \mathrm{~B}_{2}$ ' and 4$)$. When the induction occurred on nonexpanded leaves (Figs. 2A and 2A'), the folding of the leaf blade tended to be uniform, without twisting (Figs. 2B, 2B' and 5).

After completion of the leaf-folding stage, an increase in leaf tissues thickness was found to give rise to the swelling stage. At this stage, the leaf edges drew close together along their entire length, forming a narrower slit. Galls attained their definitive fusiform shape (Figs. 1C, 1C', 2C, 2C' and 6), colored a pale green similar to the mature leaf. However, gall surfaces exposed to sunlight may show a reddish-brown coloration (Fig. 6). The chamber was lined with a whitish wax with a flaky or filamentous aspect (Fig. 7). This wax derived from the inducer (Fig. 8), which, in the advanced nymphal phase, may be completely covered by it.

The beginning of the third phase in gall development - dehiscence - was marked by the opening of the slit (Figs. 1D, 1D', 2D, 2D'). At this stage the inside of the chamber was exposed, allowing the exit of nymphs in their final phase of development; the color of the gall remained green.

The senescence phase began after the nymphs emerged from the gall. The gall first turned grayish and then black, remaining attached to the branch for several months even though it was already dry.

Parasitoids were also observed in these galls (Fig. 9). They were inserted into the gall nymphs, mummifying them (Fig. 10). As soon as the parasitoids completed their development before dehiscence, they perforated the gall wall, leaving exit orifices (Fig. 11). Mummified Baccharopelma dracunculifoliae nymphs were found inside the chambers of parasitized galls.

\section{Anatomy}

Our anatomical descriptions are based on galls developed on young expanded leaves and differences from leaves not fully expanded are commented on throughout the text.

Sections through the median region of the gall in the folding phase are shown in Fig. 12. Fig. 12A represents the proximal section (closest to petiole) of a segment not yet folded. The lamina (Fig. 13) showed epidermis uniseriated, stained in reddishbrown tones, and the mesophyll was composed of spongy parenchyma placed between two sets of palisade parenchyma. Collateral vascular bundles were located in the spongy parenchyma (Figs. 13 and 19) with schizogenous secretory cavities underneath them. Stomata were present on both sides and the substomatal chambers were ample (Fig. 13). The region of the midrib (Fig. 14) was composed of epidermis, collenchyma located next to the abaxial surface, cortical parenchyma with the endodermis, and vascular system centrally disposed. The vascular system consists of abundant elements of xylem and phloem; perivascular fibers were found in larger quantities beneath the phloem. Secretory cavities were observed underneath the perivascular fibers. A trail of salivary sheath was observed leading to the xylem (Fig. 14). 

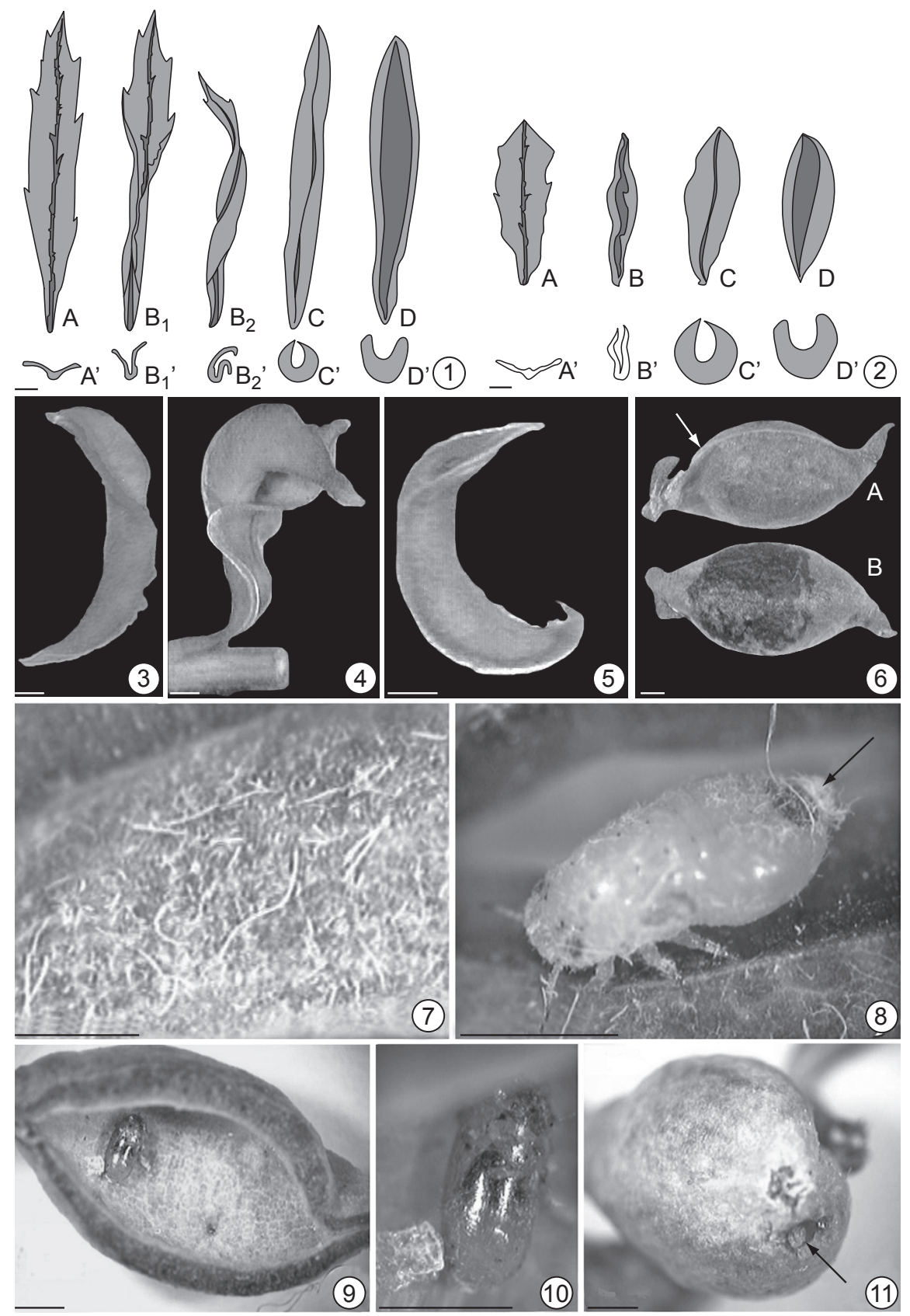

Figs. 1-11 - Gall induced by Baccharopelma dracunculifoliae on Baccharis dracunculifolia: morphological aspects: 1) Gall development on fully expanded leaf: adaxial surface (A-D), and transverse section of the middle region (A'-D'). A and A', Unaffected leaf; B1 and B1', Initial folding phase; B2 and B2', Folding phase with twist; C and C', Swelling phase; D and D', Senescence phase; 2) Gall development on incompletely expanded young leaf: adaxial surface (A-D), and transverse section of the middle region (A'-D'). A and A', Unaffected leaf; B and B', Folding phase; C and C', Swelling phase; D and D', Dehiscence phase; 3-4) Gall in folding phase (fully expanded leaf): 3) Initial phase; and 4) Twist phase; 5) Gall in folding phase (incompletely expanded leaf); 6) Gall in swelling phase: A, Shaded side showing the slit (arrow); B, Sunny side; 7) Nymphal chamber with wax; 8) Young inducer nymph with wax (arrow) at the end of abdomen; 9) Parasitized gall with mummified nymph; 10) Detail of the mummified nymph; and 11) Parasitized gall with parasitoid exit-hole (arrow). Bars $=1 \mathrm{~mm}$. 


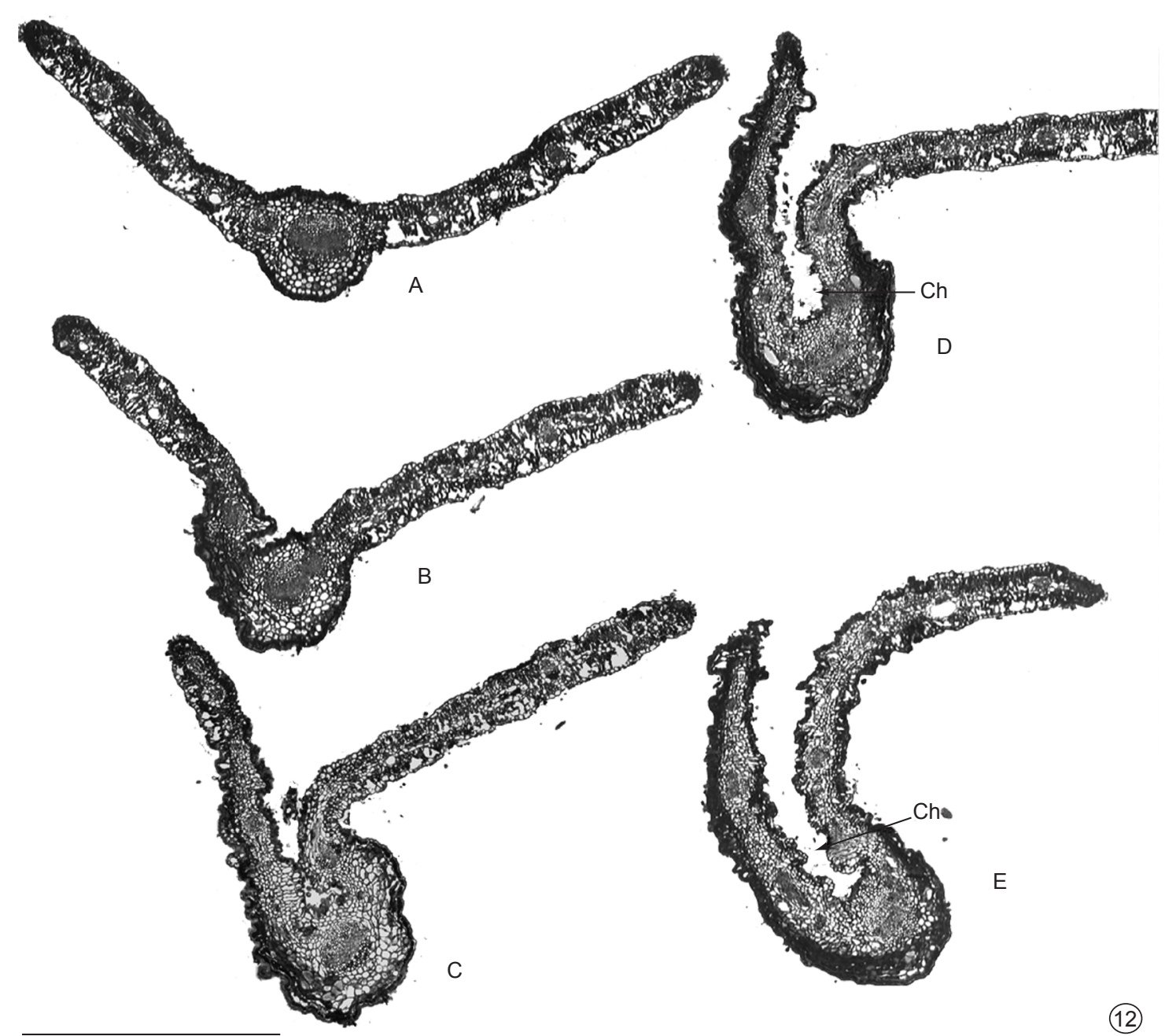

Fig. 12 - Leaf gall on Baccharis dracunculifolia: folding phase. A-E, Transverse sections (base to tip), restricted to middle region of the same gall. A) Region not folded, located near the petiole; B) Region with initial folding; C) Region more folded; D) Region folded and twisted and E) Very twisted region located near the leaf's tip. $\mathrm{Ch}=$ Chamber. Bar $=1 \mathrm{~mm}$.

Fig. 12B corresponds to a section of initially folding segment in a region anterior to $12 \mathrm{C}$, in which leaf folding was conspicuous. The tissues located in the region farthest from the midrib (Fig. 15) appeared only slightly affected while those near the midrib were more affected (Fig. 16). In the latter region, surfaces showed undulating patterns and a noticeable reduction in intercellular spaces in the mesophyll, which took on a homogenous aspect (Fig. 16). Baccharopelma dracunculifoliae nymphs were observed in the midrib region of (Figs. 17, 18). Epidermal and parenchymal cells from the abaxial surface appeared stained with basic fuchsin
(Fig. 17). On the adaxial surface (Fig. 18), cells remained clear and the areas stained with basic fucsin corresponded to the stylet sheath.

Where folding was more conspicuous (Fig. 12C-E), intense alterations occurred in the gall tissues. The gall surfaces also showed undulating patterns and the mesophyll was totally homogenous.

The secondary walls of perivascular fibers were partly or completely lignified in the region of the not yet folded gall (Figs. 14 and 19). In the folded region of the gall, some loss of fiber walls was noted (Fig. 20). In the region most strongly affected by 


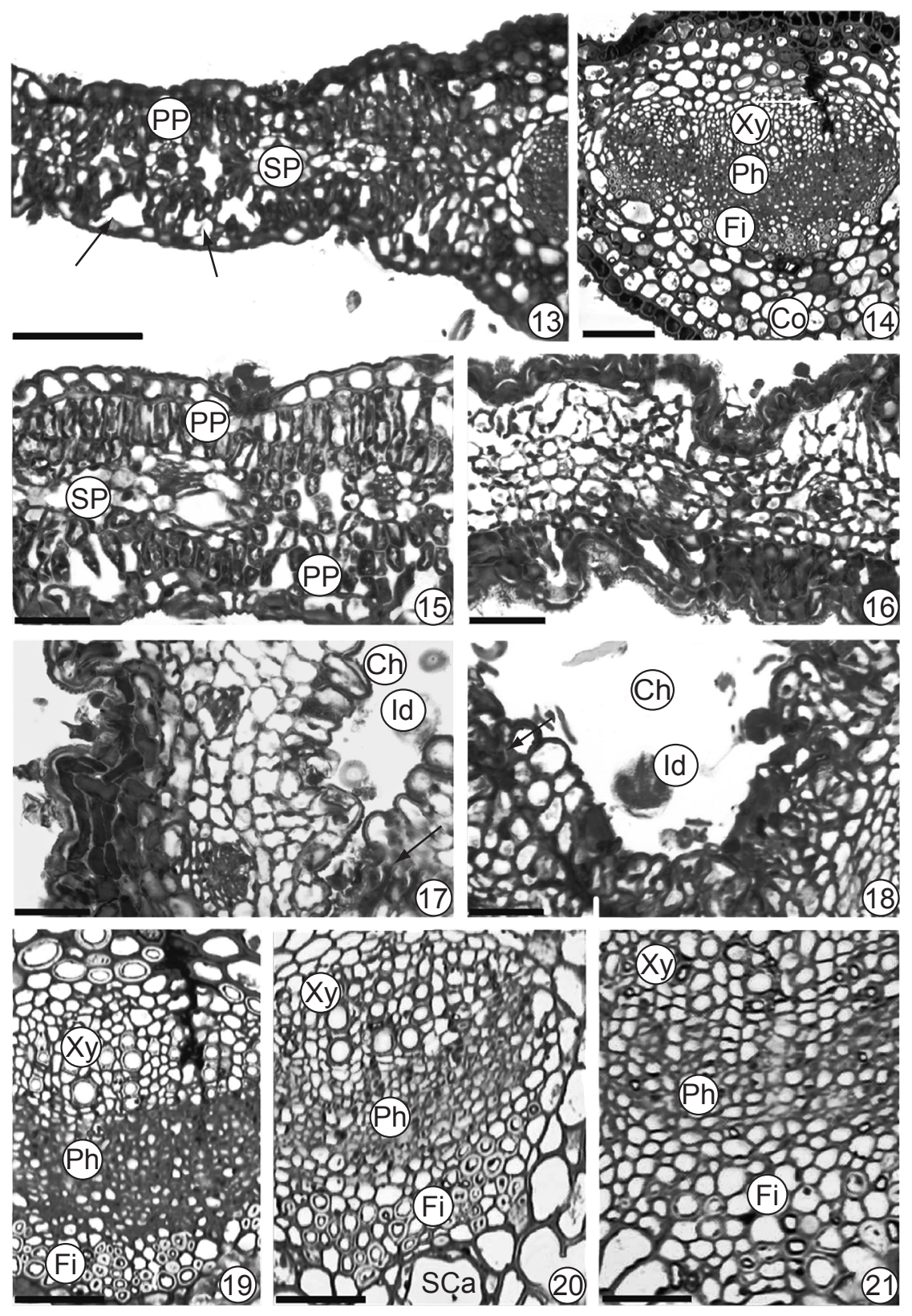

Figs. 13-21 - Leaf gall on Baccharis dracunculifolia: folding phase. Transverse sections: corresponding to Figs. 13-21. 13-14) Unfolding region (corresponding to Fig. 12A): 13) Mesophyll region showing the isobilateral structure; the substomatal chambers are ample (arrows); and 14) Midrib region showing the perivascular fibers, phloem, xylem and collenchyma. The arrow indicates the salivary sheath penetrating from epidermis to xylem; 15-18) Folding region (corresponding to Fig. 12C): 15) Region far from midrib; 16) Region close to midrib showing waving surfaces and the loss of intercellular spaces of the homogenous mesophyll; 17) Midrib region with epidermis and adjacent cells stained with basic fuchsin at abaxial surface; and 18) Midrib region with the salivary sheath stained with basic fuchsin (arrow) at adaxial surface; 19-21) Details of the midrib regions: 19) Unfolded region (corresponding to Fig. 12A); 20) Folded region (corresponding to Fig. 12C). Some perivascular fibers showed loss of their secondary walls; and 21) Folded and very twisted region (corresponding to Fig. 12E). Most of the perivascular fibers have lost their secondary walls.

13-14) bars = $100 \mu \mathrm{m} ; 15-21)$ bars = $50 \mu \mathrm{m}$. Co = Collenchyma; $\mathrm{Ch}=$ Chamber; $\mathrm{Id}=$ Inducer; Fi $=$ Fiber; $\mathrm{Ph}=\mathrm{Phloem} ; \mathrm{PP}$ $=$ Palisade Parenchyma; $\mathrm{SCa}=$ Secretory Cavity; $\mathrm{SP}=$ Spongy Parenchyma; $\mathrm{Xy}=\mathrm{Xylem}$. 
folding, several fibers showed no secondary wall, although some had kept it (Fig. 21).

Gall thickness increased in the swelling phase (Figs. 1C, 1C', 22). Trichomes were formed by the lengthening and or periclinal division of epidermal cells in the gall slit (Fig. 23). The epidermis was uniseriated in the other gall portions, while the number of parenchyma cells increased in the mesophyll (Fig. 24). Chloroplasts were observed only near the epidermis of the abaxial surface, appearing smaller, stained in darker tones, and with well-defined contours (Fig. 24). In galls initiated on incompletely expanded leaves, chloroplasts close to the epidermis of the abaxial surface presented characteristics similar to those described for galls initiated on fully expanded leaves. However, chloroplasts in more internal parenchymal cells were larger, stained pink, and had blurred contours (Fig. 25). Schizogenous secretory cavities appeared hypertrophied, and most of them showed hyaline contents (Figs. 22-24 and 26-28). Meanwhile, in the swelling phase, reticulated substances were present which stained tenuously with Sudan black; a relatively homogenous pinkish matrix was observed in the cavities near the slit in galls at the beginning of the swelling phase (Figs. 22 and 23). The epithelium was stained with basic fuchsin (Figs. 23 and 26) early in this phase, but staining was much weaker later in this phase (Figs. 27 and 28).

Salivary sheaths were strongly stained with basic fuchsin located near both the vascular bundles and secretory cavities (Figs. 27 and 28). These sheaths were found along the adaxial parenchyma, reaching the phloem and the parenchyma adjacent to the secretory cavities (Fig. 27). In some cases, the salivary sheath was found to penetrate the secretory cavities (Fig. 28).

Within the midrib region, the vascular tissues appeared altered, showing a short wedge formation in galls formed on expanded leaves (Fig. 29), whereas those formed on non-expanded leaves often displayed an elongated wedge formation (Fig. 30). Secondary walls of the perivascular fibers were no longer lignified (Fig. 31).

During the dehiscence phase, gall tissues maintained the same appearance they displayed at the end of the swelling phase, except for the opening of the slit, which was due to some hypertrophy of the tissues.
In the senescence phase (Figs. 32 and 33), necrotic tissues were observed in the gall. The necrosis began in the slit region (Fig. 33) and later spread to the internal portions of the gall.

\section{DISCUSSION}

Various hemipteran insects are capable of inducing galls (Meyer \& Maresquelle, 1983; Meyer, 1987; Rohfritsch, 1992; Wool et al., 1999; Raman, 2003). In the family Psyllidae, there are close to 350 species of gall inducers which attack, primarily, leaves of dicotyledons (Mani, 1964; Hodkinson, 1984). Baccharopelma dracunculifoliae (Psyllidae), a gall inducer on Baccharis dracunculifolia leaf, is an example of this group of galling insects. The gall is formed by the folding of leaf tissues, resulting in a singular chamber, which is linked to the external environment by a narrow slit that operates as an ostiole. The mature gall is green, succulent and fusiform.

Lara \& Fernandes's (1994) description of this gall emphasized the swelling of the leaf tissue. Their histological analysis indicated reduced hyperplasia of the tissues during the folding phase of the gall, and an intensification of this process during its swelling phase. As such, it is correct to say that the formation of this gall is a primary consequence of hyperplasia, although cell hypertrophy, largely of the schizogenous secretory cavities, also occurred.

Psyllids present five nymphal instars, from eclosion of the egg to the adult instar, displaying mechanisms that protect them from loss of humidity (Hodkinson, 1974; Raman, 2003; Gullan \& Martin, 2003). Free-feeding psyllids are more active during periods of higher humidity while others produce wax as a strategy to avoid water loss (White, 1960; Hodkinson, 1974). Pseudophacopteron sp. (Psyllidae) galls on Aspidosperma australe (Apocynaceae) maintain communication with their immediate environment through an ostiole and also have chambers lined with waxes (Christiano, 2002). In contrast, psyllid galls on Phoebe brasiliensis (Lauraceae) are entirely closed, and nymphs and chambers are devoid of any waxy secretion (Carrocini, 1989). Baccharopelma dracunculifoliae also produces wax. Waxy deposits were found in the gall chamber and wax content increased as the gall developed. As this gall has a slit, the nymphs 

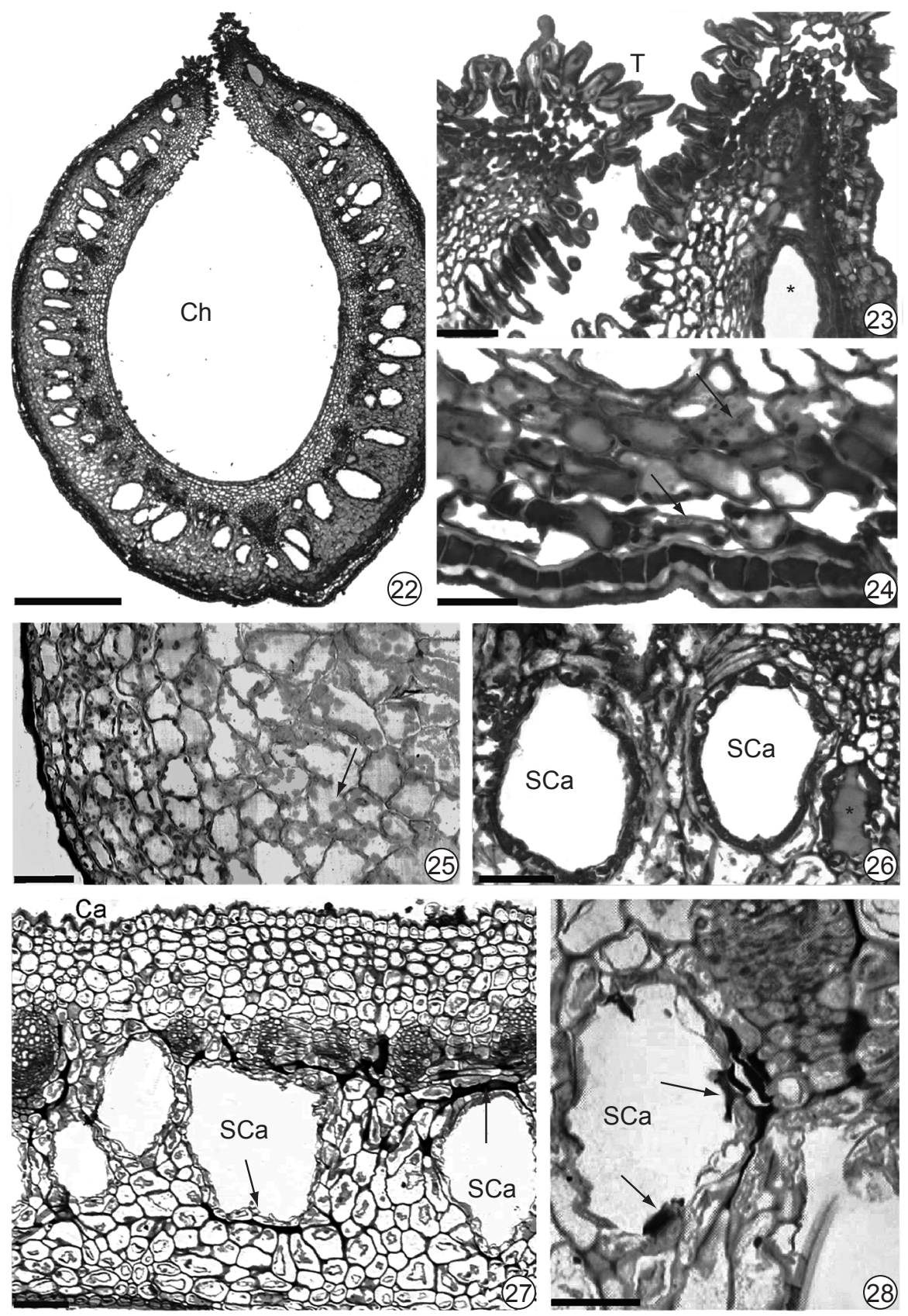

Figs. 22-28 - Leaf gall on Baccharis dracunculifolia: swelling phase. Transverse sections: corresponding to Figs. 22-26; longitudinal sections: corresponding to Figs. 27-28. 22) Hypertrophied schizogenous cavities of the gall: general view; 23) Slit region with uni- or pluricellular trichomes. Some schizogenous cavities show a pale pink matrix (*); 24) Abaxial surface: epidermal and parenchymal cells are stained with basic fuchsin. Chloroplasts (arrows) are small and smooth; 25) Gall developed in incompletely expanded leaf: peripheral chloroplasts are dark, small and smooth, but internal ones (arrow) are lighter, larger and rough; 26) Secretory cavities with epithelial cells stained with basic fuchsin; 27) Secretory cavities with weakly stained epithelial cells. Salivary sheaths (arrows) are close to vascular system and secretory cavities. 28) Detail of salivary sheath (arrows) in a secretory cavity and passing by a vascular system.

22) $\mathrm{bar}=500 \mu \mathrm{m} ; 27) \mathrm{bar}=100 \mu \mathrm{m} ; 23-26)$ and 28) bars $=50 \mu \mathrm{m}$. Ch = Chamber; $\mathrm{SCa}=$ Secretory Cavity; $\mathrm{T}=$ Trichome. 

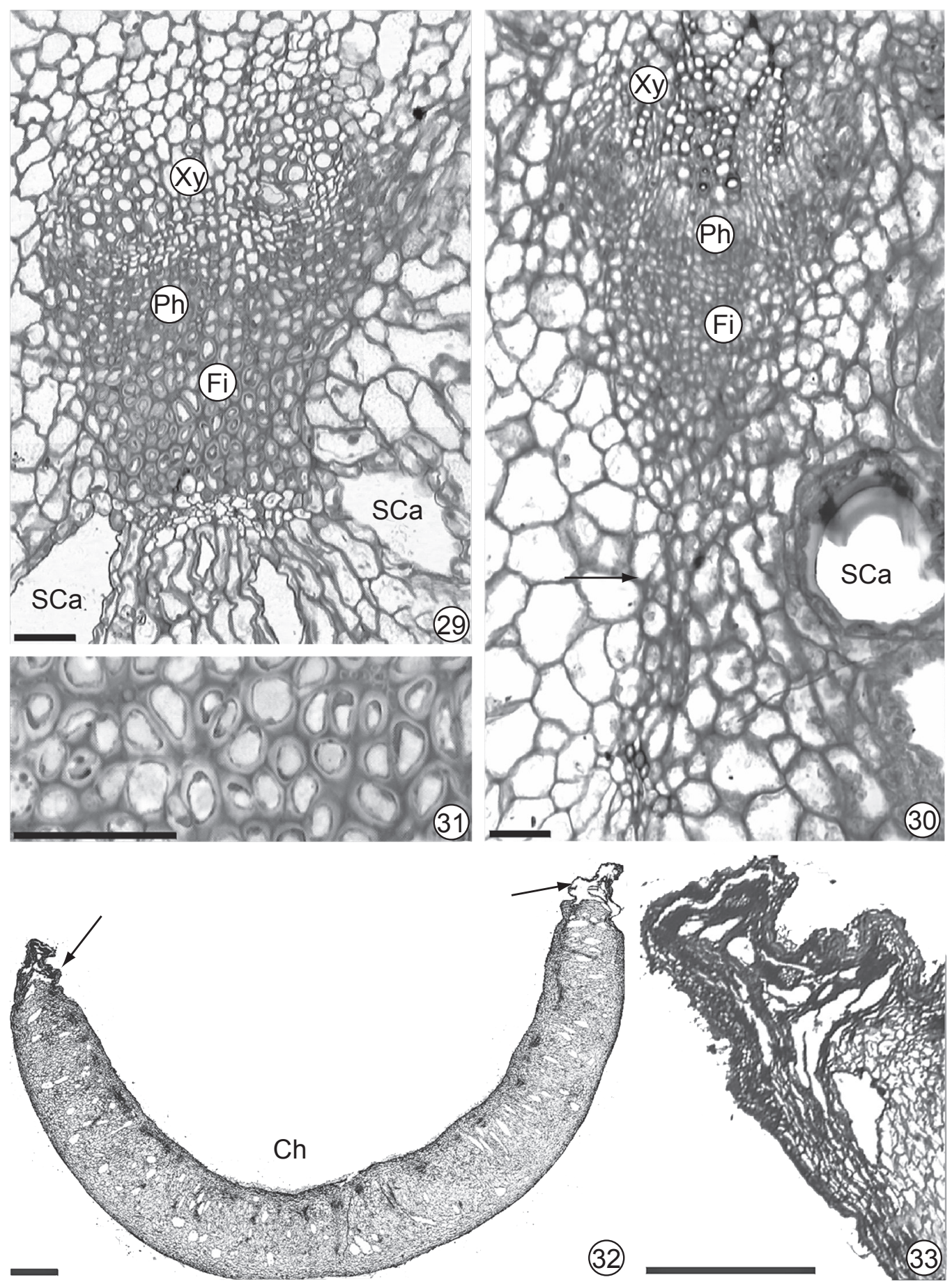

Figs. 29-33 — Leaf gall on Baccharis dracunculifolia. Transversal sections: swelling phase (corresponding to Figs. 29-31), and senescent phase (corresponding to Figs. 32-33). 29) Midrib in gall developed in fully expanded leaf: the vascular system has a short wedge shape; 30) Midrib in gall developed in leaf not fully expanded: the vascular system has a very long wedge shape (arrow); 31) Detail of perivascular fibers with non-lignified walls; 32) The necrotic tissues are close to the slit (arrows); 33) Detail of necrotic tissues.

29-31) bars $=50 \mu \mathrm{m} ; 32)$ bar = $1 \mathrm{~mm} ; 33)$ bar = $500 \mu \mathrm{m}$. Fi = Fiber; Ch = Chamber; $\mathrm{Ph}=$ Phloem; $\mathrm{SCa}=$ Secretory Cavity; Xy $=$ Xylem. 
are not totally protected from environmental conditions. Therefore, the presence of wax may diminish or buffer the effects of climate variation on the nymphs. We argue that future studies on this system should test the effects of wax production on gall abundance and differential performance in the field.

Baccharis dracunculifolia leaves sustained several tissue alterations as a result of gall induction. On the gall epidermis, the main modification was the neoformation of uni- or multicellular slit trichomes. According to Meyer \& Maresquelle (1983), the trichomes have been shown to play a protective role for the ostiole or slit in various galls.

In unaffected leaves of Baccharis dracunculifolia, schizogenous secretory cavities accumulate lipophylic substances when they reach maturity (Castro, 1987). The accumulation of these substances was not observed in galls caused by Baccharopelma dracunculifoliae. Three processes that affect secretory structures have been observed in many galls: neoformation, hypertrophy, and obstruction of the secretory system (Meyer \& Maresquelle, 1983). In the gall studied here, alteration of the secretory cavities best exemplifies the process of hypertrophy, although these structures are not apparently functional, due to the absence of lipophylic content in most of them.

Within Psyllidae galls, with few exceptions, nutritive tissue formation has not been observed (Meyer \& Maresquelle, 1983; Meyer, 1987; Rohfritsch, 1992). Hemipteran insects exhibit a sucking feeding habit; these insects introduce stylets into the tissue of plants up to the phloem. During this process, they take some time exploring the tissue and injecting viscose substances, forming a salivary sheath (Rohfritsch \& Anthony, 1992). The function of this salivary sheath is still under discussion. However, it may facilitate the penetration of the insect proboscis or prevent the plant unleashing hypersensitivity reactions to combat the damage inflicted upon it (Fernandes, 1990; Milles, 1999). Histological analyses of galls revealed the presence of basophylic substances in the salivary sheath, which according to Walton (1960), can remain in plant tissues indefinitely. Although it is acknowledged that penetration is intercellular (Rohfritsch, 1992; Raman, 2003) with dissolution of the middle lamella of the adjacent cells, Spiller et al. (1985) and Tjallingh \& Hogen-Esch (1993) revealed that this is not always the case, because the stylet can penetrate between the wall and the plasmatic membrane and may even display an intracellular path.

According to Raman (2003), the first instar of psyllid gall inducers feeds on fluids found in the parenchyma cells, without directly affecting the conducting tissue, contrary to what occurs with free-feeding sucking insects. In fact, the salivary sheath was observed in the palisade parenchyma of galls on Baccharis dracunculifolia, but in at least in one case, we confirmed that the salivary sheath reached the xylem. It is possible that the insect's proboscis was attempting to reach the phloem. Nevertheless, some hemipterous insects are known to suck from the xylem, as observed by Crews et al. (1998). In the swelling phase, the salivary sheath crossed the adaxial parenchyma and reached the phloem, as well as the parenchyma adjacent to the secretory cavities. Also in this phase, the endothelial cells lining these cavities presented relatively dense cytoplasm, which was not observed in leaves without galls. In an advanced stage of the swelling phase, the contents of the cavities appeared clear and the cells that lined the cavities no longer displayed dense cytoplasm. The presence of salivary sheaths between the endothelial cells also suggests that the inducers were feeding from the contents of these cavities. However, exploratory activity can also be seen as a cause, due to the fact that cavities in the most advanced stage of the swelling phase are apparently empty, and this phenomenon is seen even when there are no salivary sheaths nearby. More studies are necessary to define the feeding habits of Baccharopelma dracunculifoliae nymphs.

In hemipteran galls, the vascular system may be altered. For instance, in galls induced by Geoica wertheimae (Pemphigidae: Forminae) on Pistacia palestina (Anacardiaceae), up to seven layers of cells were identified as phloem (using callose staining), which facilitated access of the inducer to alimentary resources (Wool et al., 1999). An increase in phloem tissues was also observed in the Baccharopelma dracunculifoliae gall. Galls have been considered a significant drain on leaf resources (Fay \& Hartnett, 1991; Larson \& Whitham, 1991; Fay et al., 1993; Hartley, 1998; Larson, 1998; Nyman \& Julkunen-Tiito, 2000).

The loss of secondary walls in the perivascular fibers in the leaf galls induced by Baccharopelma dracunculifoliae on Baccharis dracunculifolia 
is a phenomenon already reported in other leaf galls (Arduin et al., 1991; Arduin \& Kraus, 1995; Souza et al., 2000; Arduin \& Kraus, 2001, Kraus et al., 2002). The absence of secondary walls in the perivascular fibers could favor the feeding process of the inducers, due to the lack of this mechanical barrier near the conducting tissues.

The cells of some psyllid galls can accumulate starch and phenolic substances (Raman, 2003). In galls on Aspidosperma australe induced by Pseudophacopteron, amyloplasts were present in the distal portion of the gall tissues and phenolic substances were also detected (Christiano, 2002). As for the gall on Baccharis dracunculifolia, no starch accumulation was observed in any developmental phase; phenolic substances were observed in the epidermis and in a few layers of parenchymal cells on the abaxial surface. However, Baccharis leaves without galls exhibit phenolics, according to Castro (1987), while tannins were assayed by Espírito-Santo \& Fernandes (1998). These substances have a defensive function in the plant and frequently occur abundantly within galls (Mani, 1964; Cornell, 1983; Fernandes \& Martins, 1985; Schultz, 1992). Although phenolic substances occur in large quantities, mainly in the outermost portion of the galls of Baccharis dracunculifolia studied here, these are quite highly parasitized. Thus, the defensive role of tannins for both galls and plants remains to be investigated in greater detail.

Galls induced by Baccharopelma dracunculifoliae may contain from one to as many as 21 nymphs (Espirito-Santo \& Fernandes, 2002). In most cases, specimens of opened mature galls revealed the presence of three to eight inducers, some of which were parasitized. Sperber \& Collevatti (1996) reported that inducer nymphs are frequently parasitized by Psyllophagus baccharidis (Hymenoptera: Encyrtidae), Zatropis sp. (Hymenoptera: Pteromalidae) and Brasema sp. (Hymenoptera: Eupelmidae). These three species are endoparasitoids. P. baccharidis, the primary parasitoid in this system, mummifies the nymphs and develops inside them. Parasitism is a phenomenon common to many gall systems (Cornell, 1983; Fernandes et al., 1987; RibeiroMendes et al., 2002). In the galls currently under study, Espírito-Santo \& Fernandes (1998) observed that the average death rate of a parasitized gall was approximately $21 \%$, indicating that parasitoids must be able to overcome existing chemical and mechanical defenses.

The anatomical studies on the gall induced by Baccharopelma dracunculifoliae on Baccharis dracunculifolia complements what is currently known regarding gall biology and contribute to the body of knowledge about the plasticity of plant tissues stimulated by biotic factors. In this sense, pathological tissues may reveal a potential not manifested in healthy plant tissues.

Acknowledgments - We thank two anonymous reviewers for their suggestions and critiques. The authors thank the Brazilian agencies CAPES, CNPq (Proc. 30.1776/83; 52.1772/95-ZO), FAPESP (Proc. 1997/0493-2), FAPEMIG (CBS 1950/95, CRA 2519/97) and IFS (H2487/1) for their financial support of this work.

\section{REFERENCES}

ARAÚJO, A. M., FERNANDES, G. W. \& BEDÊ, L. C., 1995, Influência do sexo e fenologia de Baccharis dracunculifolia DC. (Asteraceae), sobre herbívoros. Revista Brasileira de Entomologia, 39: 347-353.

ARDUIN, M. \& KRAUS, J. E., 1995, Anatomia e ontogenia de galhas foliares de Piptadenia gonoacantha (Fabales, Mimosaceae). Boletim de Botânica da Universidade de São Paulo, 14: 109-130.

ARDUIN, M. \& KRAUS, J. E., 2001, Anatomia de galhas de ambrosia em folhas de Baccharis concinna e Baccharis dracunculifolia (Asteraceae). Revista Brasileira de Botânica, 24: 63-72.

ARDUIN, M., KRAUS, J. E. \& VENTURELLI, M., 1991, Estudo morfológico de galha achatada em folha de Struthanthus vulgaris Mart. (Loranthaceae). Revista Brasileira de Botânica, 14: 147-156.

BURCKHARDT, D., ESPÍRITO-SANTO, M. M., FERNANDES, G. W. \& MALENOVSKÝ, I., 2003, Gall-inducing jumping plant-lice of neotropical genus Baccharopelma (Hemiptera, Psylloidea) associated with Baccharis (Asteraceae), Journal of Natural History, in press.

CARROCINI, R., 1989, Aspectos ontogenéticos, morfológicos e estruturais da galha foliar de Phoebe brasiliensis Mez. (Lauraceae). Dissertação de Mestrado do Instituto de Biociências, Universidade de São Paulo, São Paulo. 167 p.

CASTRO, M. M., 1987, Estruturas secretoras em folhas de espécies da família Asteraceae: aspectos estruturais $e$ histoquímicos. Tese de Doutorado do Instituto de Biociências, Universidade de São Paulo, São Paulo. 374 p.

CHRISTIANO, J. C. S., 2002, Respostas cecidogênicas no modelo Aspidosperma australe (Apocynaceae) Pseudophacopteron sp. (Homoptera: Phacopteronidae). Dissertação de Mestrado do Instituto de Biociências, Universidade de São Paulo, São Paulo. 117 p. 
CLARK, G., 1981, Staining Procedures. Williams \& Wilkins, Baltimore. 512p.

COLlEVATTI, R. G. \& SPERBER, C. F., 1997, The gall maker Neopelma baccharidis Burck. (Homoptera: Psyllidae) on Baccharis dracunculifolia DC. (Asteraceae): individual, local, and regional patterns. Anais da Sociedade Entomológica do Brasil, 26: 45-53.

CORNELL, H. V., 1983, The secondary chemistry and complex morphology of galls formed by the Cynipinae (Hymenoptera): why and how? American Midland Naturalist, 110: 225-234.

CREWS, L. J., MCCULlY, M. E., CANNY, M. J., HUANG, C. X. \& LING, L. E. C., 1998, Xylem feeding by spittlebug nymphs: some observations by optical and cryo-scanning electron microscopy. American Journal of Botany, 85: 449-460.

DREGER-JAUFFRET, F. \& SHORTHOUSE, J. D., 1992, Diversity of gall-inducing insect and their galls, pp. 8-33. In: SHORTHOUSE, J. D. \& ROHFRITSCH, O. (eds.), Biology of Insect-induced Galls. Oxford University Press, Oxford.

ESPIRITO-SANTO, M. M. \& FERNANDES, G. W., 2002, Host plant effects on the development and survivorship of the galling insect Neopelma baccharidis (Homoptera: Psyllidae). Austral Ecology 27: 249-257.

ESPIRITO-SANTO, M. M. \& FERNANDES, G. W., 1998, Abundance of Neopelma baccharidis (Homoptera: Psyllidae) galls on the dioecious shrub Baccharis dracunculifolia (Asteraceae). Environmental Entomology, 27: 870-876.

FARIA, M. L. \& FERNANDES, G. W., 2001, Vigour of a dioecious shrub and attack by a galling herbivore. Ecological Entomology, 26: 37-45.

FAY, P. A. \& HARTNETT, D. C., 1991, Constraints on growth and allocation patterns of Silphium integrifolium (Asteraceae) caused by a cynipid gall wasp. Oecologia, 88 : 243-250.

FAY, P. A., HARTNETT, D. C. \& KNAPP, A. K., 1993, Increased photosynthesis and water potentials in Silphium integrifolium galled by cynipid wasps. Oecologia, 93: 114-120.

FERNANDES, G. W., 1990, Hypersensitivity: a neglected plant resistance mechanism against insect herbivores. Environmental Entomology, 19: 1173-1182.

FERNANDES, G. W. \& MARTINS, R. P., 1985, As galhas: tumores de plantas. Ciência Hoje, 4: 59-64.

FERNANDES, G. W., MARTINS, R. P. \& TAMEIRÃO NETO, E., 1987, Food web relationships involving Anadiplosis sp. (Diptera: Cecidomyiidae) on Machaerium aculeatum (Leguminosae). Revista Brasileira de Botânica, 10: 117123.

FERNANDES, G. W., CARNEIRO, M. A. A., LARA, A. C. F., ALLAIN, L. R., ANDRADE, G. I., JULIÃO, G. R., REIS, T. R. \& SILVA, I. M., 1996, Galling insects on neotropical species of Baccharis (Asteraceae). Tropical Zoology, 9: 315-332.

GAHAN, P. B., 1984, Plant Histochemistry and Cytochemistry. Academic Press, London. 231 p.
GULlAN, P. J. \& MARTIN, J. H., 2003, Sternorrhyncha (jumping plant-lice, whiteflies, aphids, and scale insects). pp. 1078-1089. In: RESH, V. H. \& CARDÉ, R. T. (eds.), Encyclopedia of Insects. Academic Press, Amsterdan.

HARTLEY, S. E., 1998, The chemical composition of plant galls: are levels of nutrients and secondary compounds controlled by the gall-former? Oecologia, 113: 492-501.

HODKINSON, I. D., 1974, The biology of the Psylloidea (Homoptera): a review. Bulletin of Entomological Research, 64: 325-338.

HODKINSON, I. D., 1984, The biology and ecology of the gall-forming Psylloidea (Homoptera). pp. 59-77. In: ANANTHAKRISHMAN, N. (ed.), Biology of Gall Insects. Oxford \& IBH, New Delhi.

JOHANSEN, D. A., 1940, Plant Microtechnique. McGrawHill, New York. 523p.

KRAUS, J. E., ARDUIN, M. \& VENTURELLI, M., 2002, Anatomy and ontogenesis of hymenopteran leaf galls of Struthanthus vulgaris Mart. (Loranthaceae). Revista Brasileira de Botânica, 25: 449-458.

KRAUS, J. E., SOUZA, H. C., REZENDE, M. H., CASTRO, N. M., VECHI, C. \& LUQUE, R., 1998, Astrablue and basic fuchsin double staining of plant materials. Biotechnic \& Histochemistry, 73: 235-243.

LARA, A. C. F. \& FERNANDES, G. W., 1994, Distribution of galls of Neopelma baccharidis (Homoptera: Psyllidae) on Baccharis dracunculifolia (Asteraceae). Revista Brasileira de Biologia, 54: 661-668.

LARSON, K. C., 1998, The impact of two gall-forming arthropods on the photosynthetic rates of their hosts. Oecologia, 115: 161-166.

LARSON, K. C. \& WHITHAM, T. G., 1991, Manipulation of food resources by a gall-forming aphid: the physiology of sink-source interactions. Oecologia, 88: 15-21.

MANI, M. S., 1964, Ecology of Plant Galls. Dr Junk Publisher, The Hague. 434 p.

MEYER, J., 1987, Plant Galls and Gall Inducers. Gerbrüder Borntraeger, Berlin, 291 p.

MEYER, J. \& MARESQUELLE, H. J., 1983, Anatomie des Galles. Gebrüder Borntraeger, Berlin. 662 p.

MILLES, P. W., 1999, Aphid saliva. Biological Review, 74: 41-85.

NYMAN, T. \& JULKNEN-TIITO, R., 2000, Manipulation of the phenolic chemistry of willows by gall-inducing sawflies. Proceedings of the National Academy of Science, 97: 13184-13187.

RAMAN, A., 2003, Cecidogenetic behaviour of some gallinducing thrips, pyllides, coccids, and gall midges, and morphogenesis of their galls. Oriental Insects, 37: 359413.

RIBEIRO-MENDES, H. N., MARQUES, E. S. A., SILVA, I. M. \& FERNANDES, G. W., 2002, Influence of host-plant sex and habitat on survivorship of insect galls within the geographical range of the host-plant. Tropical Zoology, 15: 5-15.

ROHFRITSCH, O. \& ANTHONY, M., 1992, Strategies in gall induction by two groups of homopterans, pp. 102-117. In: 
SHORTHOUSE, J. D. \& ROHFRITSCH, O. (eds.), Biology of Insect-induced Galls. Oxford University Press, Oxford.

ROHFRITSCH, O., 1992, Patterns in gall development, pp. 60-86. In: SHORTHOUSE, J. D. \& ROHFRITSCH, O. (eds.), Biology of Insect-induced Galls. Oxford University Press, Oxford.

SASS, J. E., 1951, Botanical Microtechnique. $2^{\text {nd }}$ ed. The Iowa State College, Iowa. 115 p.

SCHULTZ, B. B., 1992, Insect herbivores as potential causes of mortality and adaptation in gallforming insects. Oecologia, 90: 297-299.

SIMS, B., 1974, A simple method of preparing 1-2 $\mu \mathrm{m}$ sections of large tissue blocks using glycol methacrylate. Journal of Microscopy, 101: 223-227.

SOUZA, S. C., KRAUS, J. E., ISAIAS, R. M. S. \& Neves, L. J., 2000, Anatomical and ultrastructural aspects in Ficus microcarpa L. F. (Moraceae) induced by Gynaikothrips ficorum Marchal (Thysanoptera). Acta Botanica Brasilica, 14: 57-69.

SPERBER, C. F. \& COLLEVATTI, R. G., 1996, The gall maker Neopelma baccharidis Burck. (Homoptera: Psyllidae) on Baccharis dracunculifolia (Asteraceae): success and parasitoidism density dependence. Anais da Sociedade Entomológica do Brasil, 25: 59-63.

SPILLER, N. J., KIMMINS, F. M. \& LLEWELLYN, M., 1985, Fine structure of aphid stylet pathways and its use in host plant resistance studies. Entomologia Experimentalis et Applicata, 38: 293-295.

TJALLINGH, W. F. \& HOGEN-ESCH, T., 1993, Fine structure of aphid stylet routes in plant tissues in correlation with EPG signals. Physiological Entomology, 18: 317-328.

WALTON, B. C. J., 1960, The life cycle of the hackberry gallformer, Pachypsylla celtidisgemma (Homoptera: Psyllidae). Annals of the Entomological Society of America, 53: 265277.

WHITE, T. C. R., 1960, The nymphal stage of Cardiaspina densitextura (Homoptera; Psyllidae) on leaves of Eucalyptus fasciculosa. Australian Journal of Zoology, 18: 273-293.

WOOL, D., ALONI, R., BEM-ZVI, O. \& WOLLBERG, M., 1999, A galling aphid furnishes its home with a built-in pipeline to the host food supply. Entomologia Experimentalis et Applicata, 91: 183-186. 